\title{
Geographical differentiation in access to higher education in Sweden
}

\author{
Aimee Haley
}

\begin{abstract}
Using Bourdieu's Theory of Practice, this study examines the practices of Swedish students when entering higher education. Logistic regression is used to examine relationships between the educational resources and geographical origins of students born 1973-1982 $(\mathrm{N}=382,198)$ and 1$)$ their probability of migration when entering higher education and 2) the type of institution they entered. The results indicate that students' practices differ by geographical origin, suggesting that students use migration in different ways to access higher education. For example, the students with the highest probability of migration are students originating from rural areas with high upper-secondary grades and students from large urban areas with low grades. Implications for expanding access to higher education while also creating sustainable communities are discussed.
\end{abstract}

\section{KEYWORDS}

educational access, geographical mobility, higher education, praxis, tertiary education, widening participation

In the latter half of the twentieth century, higher education systems around the world expanded and the number of higher education institutions increased. This expansion is often referred to as a massification of the higher education system (Trow 1999), through which higher education became accessible to more people in society and not only those belonging to elite groups. The Swedish system of higher education exemplifies such changes. The number of Swedes participating in and attaining degrees in higher education has grown since the 1970s. In connection with this expansion, domestic migration has also grown among young adults in the 20-29 age bracket (SOU 2007), with many students moving from less populated areas to urbanised areas for higher education and remaining there after ending their 
studies (UKÄ 2019b). Rural areas benefit from increased innovation, wages and amenities when the tertiary educated establish themselves in those areas (Faggian et al. 2017). Thus, there is reason to think that migration for the purposes of entering higher education has important consequences for the sustainability of rural communities. While many reports in the Swedish context have focused on educational choices (e.g. field of study and higher education institution) as drivers of students' migration when entering higher education (UKÄ 2019a), few studies have explored differences in the migration practices of young adults in relation to their educational resources (e.g. upper-secondary-school grades and parental education) and geographical origin, along the rural-urban spectrum.

The purpose of this study is to examine how Swedish students of different geographical origins (i.e. the regions where they lived for at least one year prior to entering higher education), and with different educational resources, vary in their migration practices when entering higher education. Hence, this study corresponds with Cattan's description of geographical mobility tendencies: 'Being mobile is not just about geographical space, but also, and probably above all, about social space' (2012: 86). In other words, students' migration when entering higher education is not just a matter of moving certain distances across physical space; students' migration tendencies are more a matter of the volume and composition of their resources (e.g. educational capital) (Bourdieu 1984, 1985, 1989). The study uses rich population data from administrative databases in Sweden to explore the relationship between students' educational resources and their migration when entering higher education, as well as the type of higher education institution they attend. The following questions guide this study:

1. Which groups of Swedish students, with respect to geographical origin and educational resources, migrate when entering higher education?

2. Which types of higher education institutions do the migrating student groups enter, taking into consideration their geographical origin and educational resources?

Answers to these questions provide important knowledge about the practices of different student groups when entering higher education, and particularly their migration tendencies, which can have social and economic repercussions for the regions and communities they move between. Knowledge of students' practices when entering higher education is necessary for educators 
to engage in educational praxis, which involves making 'morally informed and committed action' that also 'helps to shape social formations and conditions' (Kemmis 2010: 10). For instance, this study contributes knowledge that can be used by educators to devise informed, targeted educational strategies to mitigate the challenges imposed by expanding higher education access to student groups with differing geographical origins. A signifier of educational praxis is that the regions and communities in which students live will be characterised by 'honour, justice and rationality' as well as 'sustainability in its many dimensions' (Kemmis 2010: 21). Hence, this article concludes with a discussion of implications for university educators and how engaging in educational praxis can support the sustainability of rural communities in light of student migration away from these areas.

\section{Higher education expansion}

Participation in higher education has expanded the world over. From 1971 to 2013, the percentage of young adults enrolled in higher education grew from about 10 per cent to roughly 33 per cent. In connection with this expansion, higher education has become more accessible to students with diverse backgrounds (Marginson 2016). In Sweden, expansion of the higher education system has been a government directive for several decades, with reforms beginning at the end of the 1960s. Initially, student participation rates were slow to develop. Then, in the 1990s, the number of enrolled students grew. At the beginning of the 1990s the number of study places at higher education institutions nearly doubled, from about seventy-five thousand to four hundred thousand (SOU 2007). Subsequently, the number of degrees awarded rose from nearly thirty thousand in 1990 to more than seventy-five thousand in 2017 (UKÄ 2018).

In 1977, an extensive reformation of the higher education system resulted in the establishment of institutions outside major metropolitan areas (SFS 1977). The higher education system was restructured to encompass all postsecondary education, including professional institutes (e.g. teacher training institutes). With this reform, seventeen university colleges were established, mainly in small urban areas (Högskoleverket 1998). Some of these university colleges gained the status of 'new university' at the end of the 1990s, with the ability to award doctoral degrees in some subjects. In addition to these newer institutions, the Swedish higher education system is made up of old universities, which are those institutions that were granted university status 
prior to the 1990s. These institutions are located in and around large urban areas such as Stockholm, Gothenburg and Malmö. Through this expansion of the higher education system, the Swedish government sought to expand access to higher education to peripheral areas as a way to counter higher education-related migration away from these areas (Hudson 2006). Despite higher education becoming more accessible outside large urban areas, there were differences in educational offerings between the new higher education institutions and the already-existing ones, as well as differing degrees of perceived prestige. To illustrate, the old, well-established universities are considered to be full-breadth research and education institutions, while the newer institutions are generally small and medium-sized and have a regional focus and education-oriented missions. It was not until the governmental research bill of 1990 that the new universities and university colleges were endowed with their own research funding (Benner 2008 in Holmberg and Hallonsten 2015). Compared to the old universities, the amount of funding was miniscule. Even in current times, only about 12 per cent of the total annual governmental research budget is awarded to university colleges and new universities; the remaining 88 per cent goes to the old universities (Hallonsten and Holmberg 2013). Such differences in research funding and a focus on education rather than research can have implications for the perceived prestige of these institutions. The educational missions of the university colleges do not elicit as much prestige as research, and compared to the old universities, 'the new ones have been criticized for weak performances in both research and education' (Holmberg and Hallonsten 2015: 189). Such perceptions of prestige may contribute to shaping students' preferences and prompt some student groups to migrate when entering higher education.

In recent years, the Swedish government has called for increased distance education (i.e. online and blended on-campus learning), with one reason being to further counteract migration away from rural areas (Näringsdepartementet 2018). While the number of full-time students participating in distance education increased from seventeen hundred in 1994 to thirteen thousand by 2013, distance education is still rather limited. For example, less than 1 percent of individuals included in this study completed all their higher education credits through distance education. Most distance education offerings are in the form of individual courses rather than whole programmes and are mostly in the areas of teacher education, healthcare and vocational education (SOU 2015). 


\section{Higher education and migration}

With academic programmes offered through distance education being limited in Sweden as in many countries, young adults move long distances in order to attend higher education in urban areas (Patiniotis and Holdsworth 2005; UKÄ 2019b). Several factors have been identified as important in students' decisions about their migration and choice of higher education institution, including social background (Arum et al. 2007; Triventi 2013), gender (Ball et al. 2002), career interests (Brooks 2002), social networks (Foskett and Johnston 2010), and the reputation of the institution (McManus et al. 2017). Prior research in this area has centred on proximity and distance, where students' choices tend to be understood mainly in the frame of social and economic costs and benefits. For example, Christian Kjellström and Håkan Regnér (1999) found that distance to a higher education institution is important to students' decisions to participate in higher education in Sweden. If students must move long distances to attend higher education, they are likely to encounter high financial costs and weakened ties to their families due to being far away from their home region (Chudnovskaya and Kolk 2017). Hence, students must perceive the benefits of moving for higher education as outweighing the costs. Other studies have linked proximity and distance to various higher education choices. Research in the UK (Flannery and Cullinan 2014), Australia (Parker et. al. 2016), and the USA (Griffith and Rothstein 2009) shows that living near elite or prestigious universities increases the probability of attending one of these institutions. Contrary to Kjellström and Regnér (1999), Stephen Gibbons and Anna Vignoles (2012) found that distance from home has little importance for students' decisions to participate in higher education in England but was of high importance for institutional choice. For example, they found that students from low socio-economic backgrounds tend to choose higher education institutions near to where they were raised. By focusing on proximity and distance, these studies overlook geographical differences in how students enter higher education. Insight into such matters can be gained by investigating relationships between students' geographical origins along the rural-urban spectrum and subsequent patterns in higher education-related migration, which this study attempts to do.

Only a few relatively recent studies have analysed higher education-related migration and institutional choice in relation to students' geographical origin along the rural-urban spectrum. One such study by Michael Donnelly and Sol Gamsu (2018) found that geographical origin was the most important 
factor in students' (im)mobility on entering higher education in the UK, even more so than social, ethnic, and educational differences. They found that students originating from the North-East, North-West, and Wales were less likely to move for higher education and attributed this immobility to strong intergenerational links with family and local culture. With regards to choosing an institution, Helland and Heggen (2017) found that students originating from less densely populated areas tend to select those located in peripheral areas, which are also most likely to be the less prestigious university colleges and new universities. One important factor missing from these studies, which Helland and Heggen (2017) point out, is students' upper-secondary-school grades. Grades from upper secondary school are important because they have repercussions for the types of programmes and institutions into which students can gain admittance. Using Swedish register data, this study is able to contribute to this body of literature by examining relationships between students' grades, their geographical origin and their practices when entering higher education.

\section{Theorising students' practices when entering higher education}

To understand students' migration and their higher education choices, this study draws on Bourdieu's Theory of Practice (1977), and his conceptualisation of capital, habitus and field. In this study, students' higher educationrelated migration and choices of higher education institution are seen as forms of practice produced through an interplay between their educational resources (i.e. capital), their dispositions and preferences (i.e. habitus) and the arrangement of the Swedish higher education system (i.e. field).

According to Bourdieu, an individual's social position is equal to the amount and composition of their accumulated capital (i.e. their resources) (Bourdieu 1985, 1986, 1989). Thus, students' inherited capital, by way of their parents, contributes to shaping their perspective and disposition toward different higher education institutions, and subsequently contributes to their choice of an institution. Similarly, how students perceive the possibilities for migration may also be shaped by the capital that they possess. For instance, students with low economic resources may not view migration as something that is possible for them. Conversely, students from advantaged family backgrounds who move to large urban areas and enrol in prestigious universities are able to gain and reproduce their family's capital. 
These 'schemes of perceptions, thought and action' (Bourdieu 1989: 14) toward migration and choosing a higher education institution are what Bourdieu considers an individual's habitus. Bourdieu states that 'the habitus, the product of history, produces individual and collective practices, and hence, history, in accordance with the scheme engendered by history. The system of dispositions - a past which survives in the present and tends to perpetuate itself into the future by making itself present in the practices structured according to its principles' (Bourdieu 1977: 82). Put differently, habitus is a set of dispositions that just need to be realised in order to become practice.

The ways in which habitus is realised in practice relate to the specific field in question and how the field is situated. 'Field' corresponds to different segments of society and can coincide with social institutions, such as higher education systems (Bourdieu 1984). Bourdieu's theory of practice emphasises a dialectic relationship between habitus and field. Bourdieu explains: 'The habitus and the field maintain a relationship of mutual attraction, and the illusion (illusio) is determined from the inside, from impulses that push toward a self-investment in the object; but it is also determined from the outside, starting with a particular universe of objects offered socially for investment' (1999: 512). In other words, habitus does not just mirror an individual's social position, but is shaped by subjective (e.g. a student's intrinsic motivation or desires) and objective (e.g. societal structures like higher education systems) forces. These forces contribute to forming an individual's perception of possibilities and 'imposes a particular mode on desire' (Bourdieu 1999: 512-513). In the context of this study, this suggests that students' dispositions and the arrangement of the higher education system shape their practices when entering higher education.

Also important to the concept of 'field' is that capital has different values within different fields. For example, Bourdieu states that 'in a particular field, the properties, internalized in dispositions or objectified in economic or cultural goods, which are attached to agents are not all simultaneously operative; the specific logic of the field determines those which are valid in this market, which are pertinent and active in the game in question' (1984: 113). In other words, students' practices when entering the field of higher education are related to the specific composition of capital they possess. In the context of higher education, students' educational capital, a sub-form of cultural capital (Bourdieu 1984), is likely to be pertinent to shaping their practice. 
Bourdieu's Theory of Practice offers a lens for making sense of the takenfor-granted ways in which different student groups enter higher education through migration and in choosing a higher education institution. Through the lens of Bourdieu, one can understand the ways in which different student groups enter higher education as being socially appropriated (Bourdieu 1989), meaning that students with comparably available resources are expected to behave similarly (i.e. display similar practices). This theory makes possible an understanding of why different student groups display different practices when entering higher education. Such knowledge can be useful to university educators so they can engage in educational praxis, and in doing so, demonstrate commitment to expanding higher education access to student groups with diverse educational resources and geographical origins.

\section{Method}

\section{Data and population}

Register data from the Gothenburg Educational Longitudinal Database is used in this study. In Sweden, personal identification numbers are used to track individuals in various administrative databases, allowing for information on an individual's educational trajectory, residence and family background to be linked. While register data allows for an overview of students' actual behaviours when entering higher education, a limitation of the data is that it does not include information on the motivations behind their behaviours. The data used in this study encompasses the total population of individuals born 1973-1982 who resided in Sweden at age $16(\mathrm{~N}=382,198)$. The most recent data used in this study is from 2012.

Based on established requirements for students to obtain government loans for higher education studies (SFS 1999), only students who studied at least 75 per cent full-time equivalent, or forty-five credits in their first two years in higher education, were included in this study. The reason for using the 75 per cent full-time equivalent was to identify those students whose primary activity was higher education.

\section{Variables}

Two outcome variables were examined in this study: students' migration and their choice of higher education institution. The main independent vari- 
ables of interest relate to students' educational capital (Bourdieu 1984) and are operationalised by their upper-secondary-school grades and the level of their parents' education. Parental education gives some indication of the educational resources students were exposed to during their youth and of the knowledge that may have been available to help them get the most out of higher education (for instance, knowledge of which higher education institutions are perceived as the most advantageous).

- Migration refers to whether or not a student moved in order to undertake higher education. Migration occurred if students 1) attended a higher education institution located more than a hundred kilometres from their geographical origin or 2) attended a higher education institution less than a hundred kilometres from their geographical origin, but the institution they attended was not the closest in vicinity to their geographical origin. An advantage of using this measure of migration compared to more common measures (e.g. crossing county boundaries or only moving a hundred kilometres) is that it accounts for both necessary migration (i.e. moving because there are no higher education institutions within a hundred kilometres of a student's geographical origin) and elected migration (i.e. a student attending a higher education institution that is not the nearest to their geographical origin) (Haley 2017). The reason for using the distance of a hundred kilometres is to reduce the possibility of including commuter students in the number of students who migrate. The figure is based on prior research that found that moving more than a hundred kilometres constituted a significant change to the daily life of individuals in Sweden (Niedomysl et al. 2015).

- Higher education institution type is divided into three categories: university college, new university and old university. Old universities are those institutions that were granted university status prior to the 1990s. University colleges are those established following the 1977 reform, and new universities are those higher education institutions granted university status between 1990 and 2012.

- Parental education refers to whether or not a student has at least one parent who completed two or more years of higher education by the time the student reached age sixteen. This measure is divided into two categories: higher education and no higher education. 
- Upper-secondary grades are organised into five categories: low, average, good, high, and unknown/missing. The category of unknown/missing grades was included to acknowledge individuals who may have entered higher education through other qualifications, for instance through the Swedish Scholastic Assessment Test (SweSAT).

- Gender refers to an individual's biological sex as registered at age 16.

Descriptive statistics for these variables are shown in Table 1. This table shows that nearly half of the students $(\mathrm{N}=186,669)$ moved from their place of origin in order to access higher education.

Geographical origin represents a student's place of residence one year prior to beginning higher education. This paper employs a condensed version of the 1999 rural-urban classification originally developed by the Swedish Association of Local Authorities and Regions (SKL 2011). This original classification grouped Sweden's 290 municipalities into nine municipality groups. In the analysis of this paper, Rural Municipalities, Industrial Municipalities, Sparsely Populated Municipalities, Other Large Municipalities and Other Small Municipalities are merged to form the 'rural' category. 'Large urban' consists of Metropolitan Municipalities and Suburban Municipalities and 'small urban' contains Large City Municipalities and Medium City Municipalities.

\section{Analytical approach}

The analyses were carried out in two stages. In the first stage, binomial logistic regression was used to examine relationships between students' $(\mathrm{N}=382,198)$ educational capital and their migration when entering higher education. This approach was chosen for the statistical analysis because the outcome variable has two categories (i.e. migration and no migration), meaning that it is discrete and qualitative rather than continuous and quantitative. The second stage used multinomial logistic regression to examine the educational capital of migrating students $(\mathrm{N}=186,669)$ and their choice of higher education institution. Multinomial logistic regression is also used to examine relationships between an outcome variable and independent variables but is appropriate when the outcome variable has more than two categories. In the second stage of analysis, students' choice of higher education institution is the outcome variable and this is divided into three categories: old university, new university, and university college. After estimating the 
Table 1. Descriptive characteristics of students born 1973-1982, by geographical origin and whether or not they migrated for higher education

\begin{tabular}{|c|c|c|c|c|c|c|}
\hline & \multicolumn{2}{|c|}{ Rural } & \multicolumn{2}{|c|}{ Small City } & \multicolumn{2}{|c|}{ Large Urban } \\
\hline & $\%$ & $\mathbf{N}$ & $\%$ & $\mathrm{~N}$ & $\%$ & $\mathbf{N}$ \\
\hline \multicolumn{7}{|l|}{ Students who migrated } \\
\hline \multicolumn{7}{|l|}{ Gender } \\
\hline Women & 58 & 33,988 & 57 & 53,729 & 57 & 19,454 \\
\hline Men & 42 & 24,702 & 43 & 40,250 & 43 & 14,546 \\
\hline \multicolumn{7}{|l|}{ Parental Education } \\
\hline Higher Education & 43 & 25,452 & 51 & 48,274 & 56 & 19,127 \\
\hline No Higher Education & 57 & 33,238 & 49 & 45,705 & 44 & 14,873 \\
\hline \multicolumn{7}{|l|}{ Upper-Secondary Grades } \\
\hline Low & 8 & 4,374 & 8 & 7,932 & 10 & 3,424 \\
\hline Average & 36 & 21,505 & 37 & 34,608 & 39 & 13,090 \\
\hline Good & 41 & 24,097 & 39 & 36,578 & 36 & 12,359 \\
\hline High & 10 & 6,007 & 10 & 9,708 & 8 & 2,610 \\
\hline No/Missing Grades & 5 & 2,707 & 6 & 5,153 & 7 & 2,517 \\
\hline \multicolumn{7}{|c|}{ Higher Education Institution Type } \\
\hline Old University & 54 & 31,609 & 56 & 52,214 & 42 & 14,186 \\
\hline New University & 18 & 10,526 & 16 & 15,241 & 15 & 5,315 \\
\hline University College & 28 & 16,555 & 28 & 26,524 & 43 & 14,499 \\
\hline \multirow[t]{2}{*}{ Total } & 100 & 58,690 & 100 & 93,979 & 100 & 34,000 \\
\hline & \multicolumn{6}{|c|}{186,669} \\
\hline \multicolumn{7}{|c|}{ Students who did not migrate } \\
\hline \multicolumn{7}{|l|}{ Gender } \\
\hline Women & 64 & 20,387 & 59 & 49,013 & 57 & 45,578 \\
\hline Men & 36 & 11,612 & 41 & 34,797 & 43 & 34,142 \\
\hline \multicolumn{7}{|l|}{ Parental Education } \\
\hline Higher Education & 34 & 11,002 & 46 & 38,750 & 56 & 44,862 \\
\hline No Higher Education & 66 & 20,997 & 54 & 45,060 & 44 & 34,858 \\
\hline \multicolumn{7}{|l|}{ Upper-Secondary Grades } \\
\hline Low & 26 & 8,440 & 28 & 23,635 & 20 & 16,102 \\
\hline Average & 26 & 8,450 & 25 & 20,974 & 20 & 16,136 \\
\hline Good & 24 & 7,752 & 22 & 18,529 & 23 & 17,781 \\
\hline High & 17 & 5,537 & 18 & 14,967 & 28 & 22,564 \\
\hline No/Missing Grades & 7 & 1,820 & 7 & 5,705 & 9 & 7,137 \\
\hline \multicolumn{7}{|c|}{ Higher Education Institution Type } \\
\hline Old University & 28 & 9,014 & 44 & 37,176 & 86 & 68,451 \\
\hline New University & 30 & 9,641 & 21 & 17,496 & 0 & 0 \\
\hline University College & 42 & 13,344 & 35 & 29,138 & 14 & 11,269 \\
\hline \multirow[t]{2}{*}{ Total } & 100 & 31,999 & 100 & 83,810 & 100 & 79,720 \\
\hline & \multicolumn{6}{|c|}{195,529} \\
\hline Total Population & \multicolumn{6}{|c|}{382,198} \\
\hline
\end{tabular}


logistic regression models, average marginal effects (AMEs) were obtained to more clearly illustrate the relationships. AMEs are interpreted as probabilities and they allow for comparisons across groups, such as the groups of students by geographical origin in this study, with a lower risk of the results being influenced by omitted variables (Mood 2010).

\section{Results and Discussion}

\section{Migration when entering $H E$}

The results presented in Table 2 show the average marginal effects of students' educational resources on their probability of migration when entering higher education. The results indicate that differences between students with parents who have some higher education and those whose parents do not are most pronounced among students originating from rural areas. The findings show that students from rural areas with highly educated parents have a 6.8 per cent $(\mathrm{AME}=.068)$ increased probability of migration compared to students without highly educated parents. This contrasts with 3.4 per cent (AME $=.034$ ) among those originating from small urban areas and 1.4 per cent $(\mathrm{AME}=.014)$ of those from large urban areas. These findings are consistent with earlier studies showing that students with different social backgrounds use different forms of capital to access higher education, which sometimes means migrating and at other times staying put (Patiniotis and Holdsworth 2005).

Regarding upper-secondary grades, there are clear differences among students from different geographical origins. To illustrate, Table 2 shows that students originating from rural (AME $=-.136)$ and small urban (AME $=-.133)$ areas who have low upper-secondary grades have about a 13 per cent decreased probability of migration on entry to higher education, compared to their counterparts with high grades. An opposite pattern is shown for students originating from large urban areas with low grades. These students have an 11.8 per cent increased probability of migration compared to their counterparts with high grades. This increased propensity for migration may be due to their grades not meeting the requirements of the old universities proximate to where they grew up. Hence, these students may have been forced to move to small urban areas in order to access higher education and to gain the social advantages that come with attending higher education (Bourdieu 1985). For many students with low grades who origi- 
Table 2. Average marginal effects of students' educational resources on migration when entering higher education, by geographical origin

\begin{tabular}{lcccccc}
\hline \multicolumn{2}{c}{ Coef. } & SE & Coef. & SE & Coef. & SE \\
\hline Gender (ref = men) & & & & & & \\
$\quad$ Women & -.058 & .003 & -.020 & .002 & .008 & .003 \\
Parental Education (ref = No Higher Education) & & & & \\
$\quad$ Higher Education & .068 & .003 & .034 & .002 & .014 & .003 \\
Upper-Secondary Grades (ref = High) & & & & & \\
Low & -.136 & .005 & -.133 & .004 & .118 & .004 \\
Average & -.101 & .005 & -.095 & .004 & .107 & .004 \\
Good & -.062 & .004 & -.053 & .004 & .085 & .004 \\
No/Missing Grades & -.122 & .008 & -.128 & .002 & .032 & .005 \\
\hline
\end{tabular}

nated from outside large urban areas, there may not have been a need to migrate to access the new universities and university colleges, which generally have lower admissions requirements.

These results suggest that the combination of geographical origin and upper-secondary grades reinforces the immobility of some student groups while enhancing the likelihood for mobility among other groups of students. Hence, students' practices when it comes to migration may have different meanings for different groups of students, reflecting the relative value of their composition of educational capital to the opportunities for accessing higher education in their geographical location (Bourdieu 1984).

\section{Choice of higher education institution}

Focusing on students who have migrated for higher education $(\mathrm{N}=186,669)$, the results in Table 3 indicate that regardless of geographical origin, students with highly educated parents and students with high upper-secondary grades have the greatest probability of attending old universities. Regardless of geographical origin, students with highly educated parents have about a 10 per cent increased probability of attending an old university. Taken from Bourdieu's (1989) perspective, these findings support the idea that students' choices of higher education institutions may be related to inherited capital from their parents. Students with highly educated parents from large urban areas may also have received guidance from their parents that prompted them 
to enter old universities beyond their geographical area that offer prestigious academic programmes close to their areas of interest. These results suggest that their choice of higher education institution was not only a matter of the perceived prestige of the institution, but may also relate to other factors, such as academic programme offerings. Since Swedish universities are not clearly ranked according to prestige, as is the case in many other countries, students may base their institutional choices on the perceived prestige of academic programmes (Davies and Hammack 2005).

The degree of influence that upper-secondary grades have on attending an old university varies by geographical origin. For example, students from large urban areas and with low grades have a 49 per cent decreased probability (AME $=-.490)$ of attending an old university compared to students with high grades. This contrasts with low-performing students from small urban and rural areas, who respectively have a 41.5 per cent and a 39.9 per cent decreased probability of attending an old university.

Regarding patterns of attendance at new universities, there are few geographical differences to report. Geographical differences in the relationship between parental education and students' probability of attending these institutions is small. Furthermore, students with low upper-secondary grades are about 6-10 per cent more likely to attend new universities compared to those with high grades regardless of geographical origin, again indicating only slight geographical differentiation.

Turning to university colleges, students with parents who have no higher education and students with low grades are among the most likely to attend these institutions, regardless of geographical origin. However, large geographical differences in the influence of upper-secondary grades on attending university colleges were found. To illustrate, students from small urban and rural areas with low grades have about a 31 per cent increased probability of attending university colleges compared to their counterparts with high grades. However, with a 42.9 per cent increased probability, low-performing students from large urban areas have an even greater probability of attending university colleges. Geographical differences were also identified in the influence of parental education, albeit to a lesser degree. The results show that students with highly educated parents originating from large urban areas have a 10.6 per cent decreased probability of attending university colleges compared to students without highly educated parents. Conversely, students with highly educated parents from small urban and rural areas have about a 7 per cent decreased probability of attending university colleges compared to 
Table 3. Average marginal effects of educational resources on choice of higher education institution among students who migrated, by geographical origin.

\begin{tabular}{|c|c|c|c|c|c|c|}
\hline & \multicolumn{2}{|c|}{ Old University } & \multicolumn{2}{|c|}{ New University } & \multicolumn{2}{|c|}{ University College } \\
\hline & Coef. & $\mathrm{SE}$ & Coef. & $\mathrm{SE}$ & Coef. & $\mathrm{SE}$ \\
\hline \multicolumn{7}{|l|}{ Large Urban Origin } \\
\hline \multicolumn{7}{|l|}{ Gender (ref = men) } \\
\hline Women & -.032 & .005 & -.016 & .004 & .048 & .005 \\
\hline \multicolumn{7}{|c|}{ Parental Education (ref = No Higher Education) } \\
\hline Higher Education & .118 & .005 & -.012 & .004 & -.106 & .005 \\
\hline \multicolumn{7}{|c|}{ Upper-Secondary Grades (ref = High) } \\
\hline Low & -.490 & .007 & .061 & .006 & .429 & .007 \\
\hline Average & -.433 & .008 & .078 & .006 & .355 & .007 \\
\hline Good & -.333 & .008 & .100 & .006 & .234 & .007 \\
\hline No/Missing Grades & -.338 & .011 & .034 & .008 & .304 & .011 \\
\hline \multicolumn{7}{|l|}{ Small Urban Origin } \\
\hline \multicolumn{7}{|l|}{ Gender $($ ref $=$ men $)$} \\
\hline Women & -.048 & .003 & -.005 & .002 & .053 & .003 \\
\hline \multicolumn{7}{|c|}{ Parental Education (ref = No Higher Education) } \\
\hline Higher Education & .100 & .003 & -.033 & .002 & -.068 & .003 \\
\hline \multicolumn{7}{|c|}{ Upper-Secondary Grades (ref = High) } \\
\hline Low & -.415 & .004 & .097 & .003 & .318 & .004 \\
\hline Average & -.350 & .004 & .098 & .003 & .252 & .004 \\
\hline Good & -.232 & .004 & .086 & .003 & .146 & .004 \\
\hline No/Missing Grades & -.273 & .007 & .050 & .005 & .223 & .007 \\
\hline \multicolumn{7}{|l|}{ Rural Origin } \\
\hline \multicolumn{7}{|l|}{ Gender (ref = men) } \\
\hline Women & -.070 & .004 & .015 & .003 & .054 & .004 \\
\hline \multicolumn{7}{|c|}{ Parental Education (ref = No Higher Education) } \\
\hline Higher Education & .102 & .004 & -.034 & .003 & -.067 & .004 \\
\hline \multicolumn{7}{|c|}{ Upper-Secondary Grades (ref = High) } \\
\hline Low & -.399 & .006 & .087 & .005 & .311 & .005 \\
\hline Average & -.333 & .006 & .083 & .004 & .250 & .005 \\
\hline Good & -.223 & .005 & .081 & .004 & .142 & .004 \\
\hline No/Missing Grades & -.274 & .010 & .057 & .008 & .217 & .009 \\
\hline
\end{tabular}


their counterparts without highly educated parents. These results are consistent with Gibbons and Vignoles's (2012) findings that family background is an important factor in students' choice of higher education institution.

Using the perspective of Bourdieu (1984), the geographical differences found in these results suggest that students' practices of choosing a higher education institution are not only related to their educational resources (i.e. capital) but also to how these resources are valued in relation to the arrangement of the higher education system (i.e. field). To illustrate, students have different compositions of capital (e.g. low to high upper-secondary grades), which may be valued differently by the higher education institutions or programmes and their respective admissions requirements. Consequently, students' practices of choosing an institution may relate to the value of their accumulated capital in relation to the higher education institutions and their programme offerings, as well as the geographical arrangement of these institutions in proximity to where the students originated.

\section{Conclusion}

This study responds to challenges experienced in rural areas relating to students leaving when entering higher education and moving to more urbanised areas (UKÄ 2019b). These patterns may lead to difficulties in maintaining and increasing innovation, wages and amenities in the rural areas that the students leave (Faggian et al. 2017). For higher education institutions to show commitment to supporting the sustainability of these communities (Hudson 2006), educators need to deliberate on what strategies are 'right' or most appropriate for these purposes. In other words, educators need to engage in educational praxis (Kemmis 2010), and to devise morally informed strategies they need to have an understanding of students' practices when entering higher education. By examining the relationship between students' educational resources (i.e. their upper-secondary grades and parents' education) and their geographical origins on the one hand, and the probability of their migration and the type of higher education institutions they enter on the other, this study contributes to further developing knowledge of students' practices when entering higher education.

The results from this study show that having high upper-secondary grades and highly educated parents have the largest influences on the probability of migration among students originating from rural areas. In contrast, students originating from large urban areas who have low upper-secondary grades 
have a higher probability of migration. These student groups that migrate have a tendency to enter old universities and university colleges respectively, which suggests that they use migration in different ways to appropriate space in higher education (Bourdieu 1989).

Considering this finding, how then can Swedish university educators engage in educational praxis that supports sustainable solutions to the challenges encountered by widening higher education access to students originating from rural areas? One path forward is for educators to reduce the need for migration by expanding distance education, which recently gained renewed support through a government proposition (Näringsdepartementet 2018). In the proposition, the Swedish government intends to allocate funding to higher education institutions with the purpose of developing distance education, particularly geared to the needs of rural municipalities.

Since the results of this study indicate that students originating from rural areas and migrating for higher education tend to have high educational capital and enter old universities, it may be advantageous for educators at old universities to expand their distance education offerings. The availability of distance education at Sweden's universities and university colleges is quite varied, though the greatest number of programmes are offered at the new universities and university colleges (UKÄ 2017). Through expansion of the distance education offered at the old universities, young adults in rural areas could have access to what are perceived by some as Sweden's most prestigious higher education institutions, without the need for migration. Naturally, some students will need to migrate to attend programmes that require campus-based participation (e.g. programmes in the arts or sciences that require use of specific instruments or facilities), and others will be motivated to study in large urban areas for reasons other than education. However, for those students who would prefer to stay close to home and gain an education through one of Sweden's old universities, expanding distance education could be a way forward. Furthermore, current patterns of participation in distance education amongst students from rural areas suggest that there is a need for more programmes offered through distance education than just single, elective courses (UKÄ 2017); university educators, then, should place greater emphasis on developing full programmes with the needs and interests of rural communities in mind. By making adjustments to how education is made available through distance education, rather than simply carrying on as usual, higher education institutions further demonstrate a commitment to educational praxis in their work. That is, they show thought and care in how 
they meet the needs of students with different geographical origins, as well as in how they contribute to shaping the social and economic conditions of the communities from which the students originate.

\title{
Acknowledgement
}

This work was supported by the Swedish Research Council 2012-5031.

\begin{abstract}
Aimee Haley is a Senior Lecturer in the Department of Education and Special Education at the University of Gothenburg. Her research interests concern participation in higher education, education-to-work transitions and the geographies of higher education. She takes an interdisciplinary approach to her research and draws on perspectives from education, sociology and human geography.

Email: Aimee.Haley@gu.se
\end{abstract}

\section{References}

Arum, R., A. Gamoran and Y. Shavit (2007), 'More inclusion than diversion: Expansion, Differentiation and market structures in higher education', in Y. Shavit, R. Arum and A. Gamoran (eds), Stratification in Higher Education: A Contemporary Study (Stanford, CA: Stanford University Press), 1-35.

Ball, S., J. Davies, M. David and D. Reay (2002), “"Classification and judgement”: Social class and the "cognitive structures" of choice of higher education', British Journal of Sociology of Education 23, no. 1: 51-72. https://doi.org/10.1080/01425690120102854.

Benner, M. (2008), Kunskapsnation i kris? Politik, pengar och makt $i$ svensk forskning [Knowledge Nation in Crisis? Politics, Money and Power in Swedish Research] (Nora: Nya Doxa).

Bourdieu, P. (1977), Outline of a Theory of Practice (New York: Cambridge University Press).

Bourdieu, P. (1984), Distinction: A Social Critique of the Judgement of Taste (Cambridge, MA: Harvard University Press).

Bourdieu, P. (1985), 'The social space and the genesis of groups', Theory and Society 14, no. 6: 723-744. https://doi.org/10.1177/053901885024002001.

Bourdieu, P. (1986), 'The forms of capital', in J. Richardson (ed.), Handbook of Theory and Research for the Sociology of Education (New York: Greenwood), 241-258.

Bourdieu, P. (1989), 'Social space and symbolic power', Sociological Theory 7, no. 1: 14-25. https://doi.org/10.2307/202060. 
Bourdieu, P. (1999), 'The contradictions of inheritance', in P. Bourdieu, A. Accardo, G. Balazs, S. Beaud, F. Bonvin, E. Bourdieu, P. Bourgois, S. Broccolichi, P. Champagne, R. Christin, J-P. Faguer, S. Garcia, R. Lenoir, F. Oeuvrard, M. Pialoux, L. Pinto, D. Podalydes, A. Sayad, C. Soulie and L-JD. Wacquant, The Weight of the World: Social Suffering in Contemporary Society (Cambridge: Polity Press), 507-513.

Brooks, R. (2002), “"Edinburgh, Exeter, East London - or employment?” A review of research on young people's HE choices', Educational Research 44, no. 2: 217-227. https://doi.org/10.1080/00131880110107405.

Cattan, N. (2012), 'Gendering mobility: Insights into the construction of spatial concepts', in T. Creswell and T. P. Uteng (eds), Gendered Mobilities (Farnham: Ashgate Publishing Ltd.), 83-97.

Chudnovskaya, M. and M. Kolk (2017), 'Educational expansion and intergenerational proximity in Sweden', Population, Space and Place 23, 1-14. https://doi.org/10.1002/ psp.1973.

Davies, S. and F. M. Hammack (2005), 'The channeling of student competition in higher education: Comparing Canada and the U.S.', The Journal of Higher Education 76, no. 1: 89-106. https://doi.org/10.1080/00221546.2005.11772276.

Donnelly, M. and S. Gamsu (2018), 'Regional structures of feeling? A spatially and socially differentiated analysis of UK student im/mobility', British Journal of Sociology of Education 39, no. 7: 961-981. https://doi.org/10.1080/01425692.2018.1426442.

Faggian, A., I. Rajbhandari and K. R. Dotzel (2017), 'The interregional migration of human capital and its regional consequences: A review', Regional Studies 51, no. 1: 128-143. https://doi.org/10.1080/00343404.2016.1263388.

Flannery, D. and J. Cullinan (2014), 'Where they go, what they do and why it matters: The importance of geographic accessibility and social class for decisions relating to higher education institution type, degree level and field of study', Applied Economics 46, no. 24: 2952-2965. https://doi.org/10.1080/00036846.2014.916392.

Foskett, R. and B. Johnston (2010), “'A uniform seemed the obvious thing”: Experiences of careers guidance amongst potential higher education participants', Journal of Further and Higher Education 34, no. 2: 223-238. https://doi.org/ 10.1080/03098771003695486.

Gibbons, S. and A. Vignoles (2012), 'Geography, choice and participation in higher education in England', Regional Science and Urban Economics 42: 98-113. https://doi.org/ 10.1016/j.regsciurbeco.2011.07.004.

Griffith, A. L. and D. S. Rothstein (2009), 'Can't get there from here: The decision to apply to a selective college', Economics of Education Review 28: 620-628. https:// doi.org/10.1016/j.econedurev.2009.01.004.

Haley, A. (2017), 'Defining geographical mobility: Perspectives from higher education', Geoforum 83: 50-59. https://doi.org/10.1016/j.geoforum.2017.04.013.

Hallonsten, O. and D. Holmberg (2013), 'Analyzing structural stratification in the Swedish higher education system: Data contextualization with policy-history analysis', 
Journal of the American Society for Information Science and Technology 64, no. 3: 574-586. https://doi.org/10.1002/asi.22773.

Helland, H. and K. Heggen (2017), 'Regional differences in higher education choice?', Scandinavian Journal of Educational Research 62, no. 6: 884-899. https://doi.org/ 10.1080/00313831.2017.1307276.

Holmberg, D. and O. Hallonsten (2015), 'Policy reform and academic drift: Research mission and institutional legitimacy in the development of the Swedish higher education system 1977-2012', European Journal of Higher Education 5, no. 2: 181-196. https://doi.org/10.1080/21568235.2014.997263.

Högskoleverket (1998), 'De första 20 Åren: Utvecklingen vid De Mindre och Medelstora Högskolorna Sedan 1977’ [The First 20 Years: The Development of the Smaller and Medium-sized Universities since 1977] (Stockholm: Högskoleverket).

Hudson, C. (2006), 'Regional development partnerships in Sweden: A way for higher education institutions to develop their role in the processes of regional governance?', Higher Education 51, no. 3: 387-410. https://doi.org/10.1007/s10734-004-6416-3.

Kemmis, S. (2010). 'Research for praxis: Knowing doing', Pedagogy, Culture \& Society 18, no. 1: 9-27. https://doi.org/10.1080/14681360903556756.

Kjellström, C. and H. Regnér (1999), 'The effects of geographical distance on the decision to enroll in university education', Scandinavian Journal of Educational Research 43, no. 4: 335-348. https://doi.org/10.1080/0031383990430401.

Marginson, S. (2016), 'The worldwide trend to high participation higher education: Dynamics of social stratification in inclusive systems', Higher Education 72: 413-434. https://doi.org/10.1007/s10734-016-0016-X.

McManus, R., J. Haddock-Fraser, and P. Rands (2017), 'A methodology to understand student choice of higher education institutions: The case of the United Kingdom', Journal of Higher Education Policy and Management 39, no. 4: 390-405. https://doi.org/ 10.1080/1360080X.2017.1330806.

Mood, C. (2010), 'Logistic regression: Why we cannot do what we think we can do, and what we can do about it', European Sociological Review 26, no. 1: 67-82. https:// doi.org/10.1093/esr/jcp006.

Niedomysl, T., U. Ernstson, and U. Fransson (2015), 'The accuracy of migration distance measures', Population, Space and Place 23, no. 1: 1-12. https://doi.org/10.1002/ psp.1971.

Näringsdepartementet (2018), 'En sammanhållen politik för Sveriges landsbygder - för ett Sverige som håller ihop' [A coherent policy for rural Sweden - for a Sweden that stays together] 2017/18:179. https://www.regeringen.se/4950ea/contentassets/ 0ae0beff7ac24e1385d4de30424b7d02/171817900webb.pdf.

Parker, P. D., J. Jerrim, J. Anders and T. Astell-Burt (2016), 'Does living closer to a university increase educational attainment? A longitudinal study of aspirations, university entry, and elite university enrolment of Australian youth', Journal of Youth and Adolescence 45, 1156-1175. https://doi.org/10.1007/s10964-015-0386-x. 
Patiniotis, J. and C. Holdsworth (2005), "'Seize that chance!” Leaving home and transitions to higher education', Journal of Youth Studies 8, no. 1: 81-95. https://doi.org/ $10.1080 / 13676260500063710$.

SFS (1977), Svensk Författnings Samling [Swedish Code of Statutes] (1977:263), Högskoleförordningen (Stockholm: Ministry of Education and Research).

SFS (1999), Svensk Författnings Samling [Swedish Code of Statutes] (1999:1395), Studiestödslag (Stockholm: Ministry of Education and Research).

SKL (2011), 'Kommungruppsindelning 2011 - Revidering av Sveriges kommuner och landstings kommungruppsindelning' [Municipality group classification 2011 - Revision of Sweden's municipalities and county councils group classification]. (Stockholm: Sveriges Kommuner och Landsting).

SOU (2007), Flyttning och pendling i Sverige [Moving and Commuting in Sweden] (2007:35), (Stockholm: Finansdepartementet). https://www.regeringen.se/rattsliga-dokument/ statens-offentliga-utredningar/2007/05/sou-200735/ (accessed 7 September 2020).

SOU (2015), Högre utbildning under tjugo år [Higher Education during 20 Years] (2015:70), (Stockholm: Utredningen om högskolans utbildningsutbud). https://www .regeringen.se/contentassets/18f07e4081134302a3c546341337cdff/hogre-utbildning -under-tjugo-ar-sou_2015_70.pdf/ (accessed 7 September 2020).

Triventi, M. (2013), 'Stratification in higher education and its relationship with social inequality: A comparative study of 11 European countries', European Sociological Review 29, no. 3: 489-502. https://doi.org/10.1093/esr/jcr092.

Trow, M. (1999), 'From mass higher education to universal access: The American advantage’, Minerva 37: 303-328. https://www.jstor.org/stable/41827257.

UKÄ (2017), 'Distansutbildning i svensk högskola: Redovisning av ett regeringsuppdrag Report 2017:18' [Distance education in Swedish higher education: Report on a commission by the government] (Stockholm: The Swedish Higher Education Authority).

UKÄ (2018), 'Antal examina efter kön, läsåren 1977/78-2017/18' [Number of exams by gender, academic years 1977/78-2017/18] (Stockholm: The Swedish Higher Education Authority).

UKÄ (2019a), 'Studenternas rörlighet inom Sverige' [Students' mobility within Sweden] (Stockholm: The Swedish Higher Education Authority).

UKÄ (2019b), ‘Universitet och högskolor: Årsrapport 2019’ [Universities and university colleges: Annual report 2019] (Stockholm: The Swedish Higher Education Authority). 